\title{
Chemical composition, antioxidant, anti-elastase, and anti-inflammatory activities of Illicium anisatum essential oil
}

\author{
JI-YOUNG KIM ${ }^{1}$ \\ SANG-SUK KIM ${ }^{2}$ \\ TAE-HEON OH${ }^{2}$ \\ JONG SEOK BAIK ${ }^{2}$ \\ GWANPIL SONG $^{1}$ \\ NAM HO LEE ${ }^{2}$ \\ CHANG-GU HYUN ${ }^{1 *}$ \\ ${ }^{1}$ Research Group for Cosmetic Materials \\ Jeju Biodiversity Research Institute (JBRI) \\ Jeju Hi-Tech Industry \\ Development Institute (HiDI) \\ Јејu 699-943, Korea \\ ${ }^{2}$ Department of Chemistry \\ Cheju National University \\ Jеju 690-756, Korea
}

Accepted June 24, 2009
The essential oil of air-dried Illicium anisatum (Illiciaceae), obtained by hydrodistillation was analyzed by gas chromatography-mass spectrometry (GC-MS). Fifty-two components were identified in the essential oil and the main component was eucalyptol (21.8\%). The antioxidant and anti-elastase activities of the essential oil were also investigated; the essential oil exhibited moderate DPPH scavenging and anti-elastase activities. To clarify the mechanism of the anti-inflammatory activities of I. anisatum essential oil (IAE), we evaluated whether it could modulate the production of nitric oxide (NO) and prostaglandin $\mathrm{E}_{2}\left(\mathrm{PGE}_{2}\right)$ by activated macrophages. The results indicate that IAE is an effective inhibitor of LPS-induced NO and $\mathrm{PGE}_{2}$ production in RAW 264.7 cells. These inhibitory activities were accompanied by dose-dependent decreases in the expression of iNOS and COX-2 proteins and iNOS and COX-2 mRNA. In order to determine whether IAE can be safely applied to human skin, the cytotoxic effects of IAE were determined by colorimetric MTT assays in human dermal fibroblast and keratinocyte $\mathrm{HaCaT}$ cells. IAE exhibited low cytotoxicity at $100 \mu \mathrm{g} \mathrm{mL}^{-1}$. Based on these results, we suggest that IAE may be considered an anti-aging and anti-inflammatory candidate for cosmetic materials, but additional in vitro and in vivo tests have to be performed to prove its safety and efficacy.

Keywords: Illicium anisatum, Illicium religiosum, Illicium japonicum (Illiciaceae), chemical composition, cosmetics, $\mathrm{DPPH}$, elastase, inflammation

Illicium is a genus of flowering plants comprising 42 species of evergreen shrubs and small trees, and is the sole genus in the family Illiciaceae. The species are native to the tropical and subtropical regions of eastern and southeastern Asia, southeastern North America and the West Indies. Illicium anisatum (also known as I. religiosum, I. japonicum, shikimmi and skimmi) is distributed throughout eastern Asia where it is used as an orna-

*Correspondence; e-mail: cghyun@jejuhidi.or.kr 
J. Y. Kim et al.: Chemical composition, antioxidant, anti-elastase, and anti-inflammatory activities of Illicium anisatum essential oil, Acta Pharm. 59 (2009) 289-300.

mental plant. It is also found in Jeju Island, Wan-do, and the southern parts of Korea. $I$. anisatum has a long history of use in folk medicine and is used as herbal tea to treat colicky pain in infants. However, it is scientifically recognized as highly poisonous and is therefore not fit for human consumption (1). Actually I. anisatum is a neurotoxic plant because it contains sesquiterpenic lactones. Recent studies have shown that various parts of I. anisatum possess the inhibitory activities of aldose reductase, lipase and glycation as well as antioxidant activity (2-4). The phenolic compounds of leaf oil include 1-allyl-2-methoxy-4,5-methylenedioxybenzene, 4-allyl-2,6-dimethoxyphenol, 1-allyl-3-methoxy-4-(3-methylbut-2-enyloxy) benzene and 1-allyl-3,5-dimethoxy-4-(3-methylbut-2-enyloxy) benzene (5). Anisatin, a potent GABA antagonist can also be extracted from I. anisatum (6). However, the biological activity of L. anisatum essential oil (IAE) has not been described. Therefore, the objectives of the present study were to identify the main constituents of IAE and to evaluate their biological activities such as their antioxidant, anti-elastase, and anti-inflammatory activities and cytotoxicities for application to human skin.

\section{EXPERIMENTAL}

\section{Plant material}

Voucher specimens were identified by Dr. G. Song and deposited in the herbarium of the Jeju Biodiversity Research Institute. The plant was identified immediately after collection (Joongmoon area of Jeju Island in November 2007) and air-dried at room temperature for later analysis.

\section{Isolation of the essential oil}

The air-dried leaves $(1.4 \mathrm{~kg})$ of I. anisatum were powdered and immersed in $4.0 \mathrm{~L}$ of distilled water in a Clevenger-type apparatus. The percentage yield of the oil from I. anisatum was $0.24 \%(\mathrm{~V} / \mathrm{m})$. The oil was kept at $4{ }^{\circ} \mathrm{C}$ in a sealed brown vial. For the injection (splitless), $10 \mu \mathrm{L}$ of essential oil was diluted in $500 \mu \mathrm{L}$ of $\mathrm{CH}_{2} \mathrm{Cl}_{2}$, and $1 \mu \mathrm{L}$ of this diluted solution was injected.

\section{Gas chromatography-mass spectrometry}

Gas chromatographic analyses were performed on a Hewlett-Packard $6890 \mathrm{~N}$ gas chromatograph equipped with an apolar DB-1HT column $(30 \mathrm{~m} \times 0.32 \mathrm{~mm} \times 0.1 \mu \mathrm{m})$ and a split-splitless injection port (splitless mode). The temperature was set at $40{ }^{\circ} \mathrm{C}$ for $5 \mathrm{~min}$, ramped to $210^{\circ} \mathrm{C}$ at $10^{\circ} \mathrm{C} \mathrm{min}^{-1}$ and kept at $250{ }^{\circ} \mathrm{C}$ for $28 \mathrm{~min}$. Compounds were identified by their retention indices on columns and by GC-MS using a Hewlett-Packard MSD 5975 mass spectrometer at $70 \mathrm{eV}$.

\section{Determination of anti-oxidant activity}

The antioxidant reaction was carried out in $99.8 \%$ ethanol containing $0.1 \mathrm{mmol} \mathrm{L}^{-1}$ $\mathrm{DPPH}$ and essential oil $\left(0.625 \mathrm{mg} \mathrm{mL}^{-1}\right.$ to $\left.10 \mathrm{mg} \mathrm{mL}^{-1}\right)$. The scavenging effect against 
J. Y. Kim et al.: Chemical composition, antioxidant, anti-elastase, and anti-inflammatory activities of Illicium anisatum essential oil, Acta Pharm. 59 (2009) 289-300.

$\mathrm{DPPH}$ radical was assessed at room temperature for $10 \mathrm{~min}$. The change in the absorbance at $517 \mathrm{~nm}$ was measured in a 96-well reader.

\section{Elastase inhibition assay}

The activity of porcine pancreatic elastase type IV (Sigma Chem. Co., USA) was examined using $N$-succinyl-Ala-Ala-Ala- $p$-nitroanilide as the substrate and by measuring the release of $p$-nitroaniline at $410 \mathrm{~nm}$. The reaction was carried out in $200 \mathrm{mmol} \mathrm{L}^{-1}$ Tris- $\mathrm{HCl}$ buffer ( $\mathrm{pH}$ 8.0) containing $0.2 \mathrm{mmol} \mathrm{L}^{-1} \mathrm{~N}$-Suc-(Ala) $)_{3}$-nitroanilide and 0.104 unit $\mathrm{mL}^{-1}$ elastase. Essential oil $\left(0.625 \mathrm{mg} \mathrm{mL}^{-1}\right.$ to $\left.10 \mathrm{mg} \mathrm{mL}^{-1}\right)$ was added to the reaction mixture, and the elastase inhibition was assessed at $25^{\circ} \mathrm{C}$. The reaction mixture was pre-incubated for $10 \mathrm{~min}$ before addition of the substrate. The change in absorbance was measured at $410 \mathrm{~nm}$ in a 96-well reader.

\section{Cell culture}

The murine macrophage cell line RAW 264.7 was purchased from the Korean Cell Line Bank (KCLB; Korea). RAW 264.7 cells were cultured in Dulbecco's modified Eagle's medium (DMEM; GIBCO Inc., USA) supplemented with $100 \mathrm{U} \mathrm{mL}^{-1}$ of penicillin, $100 \mu \mathrm{g}$ $\mathrm{mL}^{-1}$ of streptomycin and $10 \%$ of fetal bovine serum (FBS, GIBCO Inc.). The cells were incubated in an atmosphere of $5 \% \mathrm{CO}_{2}$ at $37{ }^{\circ} \mathrm{C}$ and were subcultured every 3 days.

\section{Determination of nitric oxide (NO) production}

After pre-incubation of RAW 264.7 cells $\left(1.5 \times 10^{5}\right.$ cells $\left.\mathrm{mL}^{-1}\right)$ with lipopolysacharide (LPS, $1 \mu \mathrm{g} \mathrm{mL}^{-1}$ ) for 24 hours, the quantity of nitrite in the culture medium was measured as an indicator of NO production. Briefly, $100 \mu \mathrm{L}$ of cell culture medium was mixed with $100 \mu \mathrm{L}$ of Griess reagent ( $1 \%$ sulfanilamide and $0.1 \%$ naphthylethylenediamine dihydrochloride in $2.5 \%$ phosphoric acid), the mixture was incubated at room temperature for $10 \mathrm{~min}$, and the absorbance at $540 \mathrm{~nm}$ was measured in a microplate reader. Fresh culture medium was used as a blank in every experiment. The quantity of nitrite was determined from a sodium nitrite standard curve. All experiments were performed in triplicate.

\section{Lactate dehydrogenase (LDH) cytotoxicity assay}

RAW 264.7 cells $\left(1.5 \times 10^{5}\right.$ cells $\left.\mathrm{mL}^{-1}\right)$ plated in 96-well plates were pre-incubated for $18 \mathrm{~h}$ and then treated with LPS $\left(1 \mu \mathrm{g} \mathrm{mL}^{-1}\right)$ plus aliquots of the essential oil $(25,50$, and $100 \mu \mathrm{g} \mathrm{mL}^{-1}$ ) at $37^{\circ} \mathrm{C}$ for $24 \mathrm{~h}$. The release of lactate dehydrogenase (LDH) from RAW 264.7 cells was used to detect cytotoxicity and was measured at the end of each proliferation experiment. LDH leakage is a means of measuring membrane integrity as a function of the amount of cytoplasmic LDH released from the cytosol into the medium. $\mathrm{LDH}$ activity was determined from the production of NADH during the conversion of lactate to pyruvate $(7,8)$ and was measured using an LDH cytotoxicity detection kit (Promega, USA). Briefly, the culture medium was centrifuged at 12,000 rpm for $3 \mathrm{~min}$ at room temperature. The cell-free culture medium $(50 \mu \mathrm{L})$ was then collected and incubated with $50 \mu \mathrm{L}$ of the reaction mixture from the cytotoxicity detection kit for $30 \mathrm{~min}$ at 
J. Y. Kim et al.: Chemical composition, antioxidant, anti-elastase, and anti-inflammatory activities of Illicium anisatum essential oil, Acta Pharm. 59 (2009) 289-300.

room temperature in the dark. $1 \mathrm{~mol} \mathrm{~mL}^{-1} \mathrm{HCl}(50 \mu \mathrm{L})$ was added to each well to stop the enzymatic reaction. The optical density of the solution at a wavelength of $490 \mathrm{~nm}$ was then measured using an ELISA plate reader. Percent cytotoxicity was determined relative to the control group. All experiments were performed in triplicate.

\section{Determination of $P G E_{2}$ production}

Cells were treated with LPS $\left(1 \mu \mathrm{g} \mathrm{mL}^{-1}\right)$ for $24 \mathrm{~h}$ to allow cytokine production. The $\mathrm{PGE}_{2}$ concentration in the culture medium was quantified using a competitive enzyme immunoassay kit (R\&D Systems, USA) according to the manufacturer's instructions. The production of $\mathrm{PGE}_{2}$ was measured relative to that following control treatment. All experiments were performed in triplicate.

\section{RNA isolation and RT-PCR analysis}

Total RNA from LPS-treated RAW 264.7 cells was prepared with Tri-Reagent (MRC, USA) according to the manufacturer's protocol. RNA was stored at $-70{ }^{\circ} \mathrm{C}$ until use. One $\mu \mathrm{g}$ RNA was reverse transcribed with M-MuLV reverse transcriptase (Promega, USA), oligo dT-18 primer, dNTP $\left(0.5 \mu \mathrm{mol} \mathrm{mL}{ }^{-1}\right)$ and $1 \mathrm{U}$ RNase inhibitor. The reaction cocktail was sequentially incubated at $70{ }^{\circ} \mathrm{C}$ for $5 \mathrm{~min}, 25^{\circ} \mathrm{C}$ for $5 \mathrm{~min}$, and $37^{\circ} \mathrm{C}$ for $60 \mathrm{~min}$, and $\mathrm{M}-\mathrm{MuLV}$ reverse transcriptase was then inactivated by heating at $70{ }^{\circ} \mathrm{C}$ for $10 \mathrm{~min}$. Polymerase chain reaction (PCR) was performed in reaction buffer [CDNA, 1.25 U Taq DNA polymerase (Promega), 3'- and 5'-primer (50 $\mu \mathrm{mol} \mathrm{mL}^{-1}$ each) and $200 \mathrm{mmol} \mathrm{mL}^{-1} \mathrm{dNTP}$ in $200 \mathrm{mmol} \mathrm{mL}^{-1}$ Tris- $\mathrm{HCl}$ buffer ( $\mathrm{pH}$ 8.4) containing $500 \mathrm{mmol} \mathrm{mL}^{-1} \mathrm{KCl}$ and 1-4 mmol $\mathrm{mL}^{-1} \mathrm{MgCl}_{2}$ ]. PCR was performed in a DNA gene cycler (BIO-RAD, USA) with amplification for 30 cycles of $94{ }^{\circ} \mathrm{C}$ for $45 \mathrm{~s}$ (denaturing), $60-65{ }^{\circ} \mathrm{C}$ for $45 \mathrm{~s}$ (annealing) and $72{ }^{\circ} \mathrm{C}$ for $1 \mathrm{~min}$ (primer extension). The primers used in this study were: $\beta$-actin (forward primer 5'-GTGGGCCGCCCTAGGCACCAG-3' and reverse primer 5'-GGAGGAAGAGGATGCGGCAGT-3'), iNOS (forward primer 5'-CCCTTCCGAAGTTTCTGGCAGCAGC-3' and reverse primer 5'-GGCTGTCAGAGCCTCGTGGCTTTGG-3'), COX-2 (forward primer 5'-CACTACATCCTGACCCACTT-3' and reverse primer 5'-ATGCTCCTGCTTGAGTATGT$\left.-3^{\prime}\right)$. PCR products were electrophoresed in $1.5 \%$ agarose gels and stained with ethidium bromide. The $\beta$-actin, iNOS and COX-2 primers produced the expected amplified products of 603, 496 and $696 \mathrm{bp}$, respectively.

\section{Immunoblotting}

RAW 264.7 cells were pre-incubated for $18 \mathrm{~h}$ and then stimulated with LPS $\left(1 \mu \mathrm{g} \mathrm{mL} \mathrm{m}^{-1}\right)$ in the presence of test materials for $24 \mathrm{~h}$. After incubation, the cells were collected and washed twice with cold PBS (phosphate-buffered saline). Cells were lysed in lysis buffer [50 mmol mL ${ }^{-1}$ Tris- $\mathrm{HCl}$ (pH 7.5), $150 \mathrm{mmol} \mathrm{mL}^{-1} \mathrm{NaCl}, 1 \%$ Nonidet P-40, 2 mmol mL $\mathrm{mL}^{-1}$ EDTA, $1 \mathrm{mmol} \mathrm{mL}^{-1}$ EGTA, $10 \mathrm{mmol} \mathrm{mL}{ }^{-1} \mathrm{NaF}, 1 \mathrm{mmol} \mathrm{mL}{ }^{-1}$ dithiothreitol, $1 \mathrm{mmol} \mathrm{mL}^{-1}$ phenylmethylsulfonyl fluoride, $25 \mu \mathrm{g} \mathrm{mL}^{-1}$ aprotinin, $25 \mu \mathrm{g} \mathrm{mL}^{-1}$ leupeptin] and kept on ice for $30 \mathrm{~min}$. The cell lysates were centrifuged at $12000 \times \mathrm{g}$ at $4{ }^{\circ} \mathrm{C}$ for $15 \mathrm{~min}$ and the supernatants were stored at $-70{ }^{\circ} \mathrm{C}$ until use. Protein concentration was measured by the Bradford method (9). Aliquots of the lysates (30-50 $\mu \mathrm{g}$ of protein) were separated on 8-12\% SDS-polyacrylamide gels and transferred onto polyvinylidene fluoride (PVDF) 
J. Y. Kim et al.: Chemical composition, antioxidant, anti-elastase, and anti-inflammatory activities of Illicium anisatum essential oil, Acta Pharm. 59 (2009) 289-300.

membranes (BIO-RAD) with glycine transfer buffer [192 mmol mL $\mathrm{m}^{-1}$ glycine, $25 \mathrm{mmol}$ $\mathrm{mL}^{-1}$ Tris- $\mathrm{HCl}(\mathrm{pH} 8.8), 20 \% \mathrm{MeOH}(V / V)$ ]. After blocking nonspecific sites with $5 \%$ nonfat dried milk, the membranes were incubated with specific primary mouse monoclonal anti-iNOS Ab (1:1000, Calbiochem, USA) or rabbit polyclonal anti-COX-2 Ab (1:1000, BD Biosciences Pharmingen, USA) at $4{ }^{\circ} \mathrm{C}$ overnight. Each membrane was further incubated for $30 \mathrm{~min}$ with a secondary peroxidase-conjugated goat IgG (1:5000, Amersham Pharmacia Biotech, UK) to mouse or rabbit, respectively. Immunoactive proteins were detected using an enhanced chemiluminescence (ECL) Western blotting detection kit (Amersham Biosciences, USA).

\section{Cytotoxicity assay of I. anisatum essential oil}

Human normal fibroblast and HaCaT cells were cultured in DMEM medium containing $10 \%$ fetal bovine serum and $1 \%$ penicillin-streptomycin at $37^{\circ} \mathrm{C}$ in a humidified $95 \%$ air $/ 5 \% \mathrm{CO}_{2}$ atmosphere. Cells were seeded on 96-well plates and drug treatment began $24 \mathrm{~h}$ after seeding. The general viability of cultured cells was determined by the 3-(4,5-dimethyl-2-thiazolyl)-2,5-diphenyl-2H-tetrazolium bromide (MTT) assay, in which MTT was reduced to formazan in viable cells. After human normal fibroblast and $\mathrm{HaCaT}$ cells were incubated with various concentrations of IAE for $48 \mathrm{~h}$ at $37^{\circ} \mathrm{C}$ in a $5 \%$ $\mathrm{CO}_{2}$ atmosphere, MTT ( $1 \mathrm{mg} \mathrm{mL}^{-1}$ in PBS) was added to each well in a 1/10 volume of medium. Cells were incubated at $37^{\circ} \mathrm{C}$ for $3 \mathrm{~h}$, and dimethylsulfoxide (DMSO) was added to dissolve the formazan crystals. The absorbance was then measured at $570 \mathrm{~nm}$ with a spectrophotometer (PowerWave X340, Bio-Tek Instruments, Inc., USA).

\section{Statistical analysis}

Student's $t$-test and one-way ANOVA were used to determine the statistical significance of differences between the values for the various experimental and control groups. Data are expressed as mean $\times$ standard errors $(\mathrm{SEM})$ and the results were taken from at least three independent experiments performed in triplicate.

\section{RESULTS AND DISCUSSION}

\section{Chemical composition of the essential oil}

The general chemical profile of the essential oil, the percentage content, and the retention indices of the constituents are summarized in Table I. A total of 52 volatile constituents were tentatively identified on the basis of their mass spectra, which were compared to those in the literature. The retention indices were calculated using a homologous series of $n$-alkanes $C_{6}-C_{25}$. The peak areas of individual compounds were related to total peak areas of compounds detected by GC. Only the components with matches exceeding $80 \%$, which represented about $85.6 \%$ of the essential oil from I. anisatum, were characterized. Eucalyptol (21.8 \%), sabinene (5.3\%), $\alpha$-terpinenyl acetate $(4.9 \%)$, kaurene $(4.5 \%)$, isopimaradiene $(3.2 \%)$, safrol $(2.7 \%)$, $\beta$-linalool $(2.6 \%), \delta$-cadinene $(2.2 \%)$, $\alpha$-cadinol (2.2), and terpene-4-ol (1.9\%) were the main constituents of the essential oil of 
J. Y. Kim et al.: Chemical composition, antioxidant, anti-elastase, and anti-inflammatory activities of Illicium anisatum essential oil, Acta Pharm. 59 (2009) 289-300.

Table I. Identified components in the essential oil of I. anisatum

\begin{tabular}{|c|c|c|c|}
\hline Constituent & $\begin{array}{l}\text { Retention time } \\
\text { (min) }\end{array}$ & $\begin{array}{l}\text { Retention } \\
\text { index }\end{array}$ & $\begin{array}{c}\text { Peak area } \\
(\%)\end{array}$ \\
\hline Toluene & 2.142 & 782.7 & 1.2 \\
\hline$\alpha$-Thujene & 5.144 & 913.2 & 0.2 \\
\hline$\alpha$-Pinene & 5.293 & 916.8 & 1.8 \\
\hline Camphene & 5.662 & 925.6 & 0.5 \\
\hline Sabinene & 6.720 & 950.7 & 5.3 \\
\hline$\beta$-Myrcene & 7.777 & 975.9 & 0.7 \\
\hline$\alpha$-Terpinene & 8.692 & 997.7 & 1.3 \\
\hline o-Cymene & 8.912 & 1002.1 & 0.2 \\
\hline Eucalyptol & 9.284 & 1008.6 & 21.8 \\
\hline Limonene & 9.369 & 1010.1 & 1.1 \\
\hline trans- $\beta$-Ocimene & 10.631 & 1032.0 & 0.2 \\
\hline$\gamma$-Terpinene & 10.647 & 1032.3 & 2.0 \\
\hline$\alpha$-Terpinolene & 12.493 & 1064.3 & 0.6 \\
\hline$\beta$-Linalool & 13.455 & 1081.0 & 2.6 \\
\hline Camphor & 14.399 & 1097.4 & 0.3 \\
\hline Terpene-4-ol & 17.307 & 1143.3 & 1.9 \\
\hline$\alpha$-Terpineol & 18.134 & 1156.2 & 1.0 \\
\hline Safrol & 23.703 & 1243.7 & 2.7 \\
\hline Bornyl acetate & 24.171 & 1251.1 & 0.3 \\
\hline$\beta$-Phellandrene & 26.248 & 1283.8 & 0.6 \\
\hline Eugenol & 28.170 & 1314.5 & 0.8 \\
\hline$\alpha$-Terpinenyl acetate & 28.446 & 1318.9 & 4.9 \\
\hline$\alpha$-Copaene & 30.121 & 1345.9 & 0.5 \\
\hline$\beta$-Bourbonene & 30.385 & 1350.2 & 0.3 \\
\hline Eremophilene & 31.145 & 1362.4 & 0.2 \\
\hline$\beta$-Caryophyllene & 32.247 & 1380.2 & 1.7 \\
\hline$\alpha$-Humulene & 34.140 & 1409.6 & 0.4 \\
\hline Germacrene D & 35.800 & 1433.6 & 1.7 \\
\hline Bicyclogermacrene & 36.819 & 1448.3 & 0.5 \\
\hline Germacrene A & 37.232 & 1454.3 & 0.4 \\
\hline$\alpha$-Amorphene & 38.104 & 1466.9 & 0.8 \\
\hline$\delta$-Cadinene & 39.199 & 1482.7 & 2.2 \\
\hline Caryophyllene oxide & 41.865 & 1521.3 & 0.5 \\
\hline Diethyl phthalate & 42.547 & 1542.7 & 1.3 \\
\hline 2,3,5,6-Tetramethylanisole & 42.868 & 1549.0 & 0.4 \\
\hline Methoxyeugenol & 43.336 & 1558.3 & 0.5 \\
\hline Cubenene & 43.625 & 1564.0 & 0.2 \\
\hline
\end{tabular}


J. Y. Kim et al.: Chemical composition, antioxidant, anti-elastase, and anti-inflammatory activities of Illicium anisatum essential oil, Acta Pharm. 59 (2009) 289-300.

\begin{tabular}{lccr}
$\tau$-Muurolol & 45.198 & 1595.2 & 1.8 \\
Copaene & 45.349 & 1598.2 & 0.4 \\
a-Cadinol & 45.638 & 1605.9 & 2.2 \\
2-Hydroxy-4-isopropyl-7-methoxytropone & 48.387 & 1687.4 & 1.1 \\
Isoeugenol E & 48.575 & 1693.0 & 0.5 \\
2-Methylthio-3,4-dihydronaphtho[2,1-c]thiophene & 50.222 & 1757.4 & 0.6 \\
6-Allyl-1,3-benzodioxol-5-ol & 51.053 & 1791.2 & 0.4 \\
3,6-Dimethoxy-2-ethylbenzalaldehyde & 51.560 & 1813.0 & 2.7 \\
Ent-pimara-8(14),15-diene & 53.664 & 1907.8 & 2.8 \\
Isopimaradiene & 54.226 & 1936.3 & 3.2 \\
Pimara-8(9),15-diene & 54.733 & 1962.0 & 0.1 \\
Kaurene & 54.948 & 1972.9 & 4.5 \\
Abietatriene & 55.338 & 1992.7 & 0.2 \\
2',3'-Dimethyl-2,3,4,5,6-pentafluorobiphenyl & 55.928 & 1999.2 & 1.4 \\
Ferruginol & 59.460 & 2221.4 & 0.1 \\
& & Total & 85.6 \\
\hline
\end{tabular}

The GC/MS retention indices were calculated using a homologous series of $n$-alkanes $\mathrm{C}_{6}-\mathrm{C}_{25}$. Components were tentatively identified based on library and literature searches and only those components showing matches exceeding $80 \%$ were selected.

I. anisatum. In contrast, the main compounds identified by Cook and Howard (10) were cineole $(18.1 \%)$, linalool (10.1\%), methyleugenol (9.8\%), $\alpha$-terpinenyl acetate $(6.8 \%)$, and safrol $(6.6 \%)$. This difference in the main components may be due to the provenance of the plant, harvest time or development stage, extraction technique, or the use of fresh or dried plant material. All of these factors influence the chemical composition and biological activity.

\section{Anti-elastase and antioxidant activities of the essential oil}

IAE was investigated for elastase inhibition. In this assay, IAE produced more than $70 \%$ inhibition at $2.5 \mathrm{mg} \mathrm{mL}^{-1}$. In order to determine the $I C_{50}$ value for IAE, we conducted experiments to assess the dose-response relationships. The $I C_{50}$ value for IAE was $1.79 \mathrm{mg} \mathrm{mL}^{-1}$. IAE was also investigated in a DPPH assay. In this assay, IAE had good antioxidant activity $\left(I C_{50}, 3.83 \mathrm{mg} \mathrm{mL}^{-1}\right)$. These activities can be attributed to the presence of eucalyptol, sabinene, $\alpha$-terpinenyl acetate, kaurene, isopimaradiene, safrol and $\beta$-linalool. Considering the different groups of chemical compounds present in IAE, it is most likely that the biological activity is attributable to a synergism between components. Eucalyptol and kaurene have been reported to have significant anti-oxidant activity (11-13).

\section{Effects of IAE on LPS-induced NO and PGE 2 production and cell viability}

To investigate the effect of IAE on NO production, we measured the accumulation of nitrite, a stable oxidized product of NO, in culture media. NO production was examined in RAW 264.7 cells stimulated with LPS for $24 \mathrm{~h}$ in the presence or absence of IAE. 
J. Y. Kim et al.: Chemical composition, antioxidant, anti-elastase, and anti-inflammatory activities of Illicium anisatum essential oil, Acta Pharm. 59 (2009) 289-300.

Nitrite levels in LPS-stimulated cells increased significantly compared to control cells. As shown in Fig. 1a, IAE (25, 50 and $\left.100 \mu \mathrm{g} \mathrm{mL}^{-1}\right)$ inhibited markedly and dose-dependently the LPS-induced NO production by RAW 264.7 cells. There was no basal NO production in cells incubated only with IAE without LPS (data not shown). The numbers of viable activated macrophages were not altered by IAE as determined by LDH assays, indicating that the inhibition of NO synthesis by IAE was not simply due to cytotoxic effects.

We further examined the effects of IAE on $\mathrm{PGE}_{2}$ production in LPS-stimulated RAW 264.7 macrophages. When macrophages were stimulated with LPS $\left(1 \mu \mathrm{g} \mathrm{mL}^{-1}\right)$ for $24 \mathrm{~h}$, the levels of $\mathrm{PGE}_{2}$ increased in the culture medium. As shown in Fig. 1b, IAE $(25,50$, and $100 \mu \mathrm{g} \mathrm{mL}^{-1}$ ) suppressed the LPS-induced $\mathrm{PGE}_{2}$ production in a dose-dependent manner.

\section{Effects of IAE on LPS-induced iNOS and COX-2 protein and mRNA expressions}

Western blot and RT-PCR analyses were performed to determine whether the inhibitory effects of IAE on pro-inflammatory mediators ( $\mathrm{NO}$ and $\mathrm{PGE}_{2}$ ) were related to the modulation of iNOS and COX-2 expression. In unstimulated RAW 264.7 cells, iNOS and COX-2 protein and mRNA were not detected, but LPS remarkably upregulated their pro-
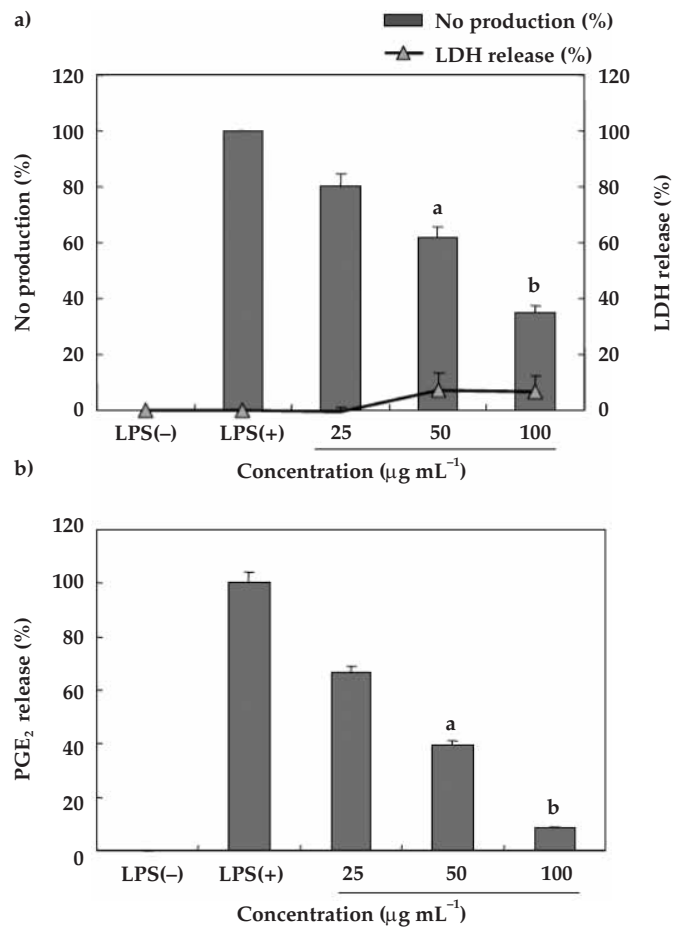

Fig. 1. Inhibitory effect of IAE on cell viability and nitric oxide and $\mathrm{PGE}_{2}$ production in RAW 264.7 cells. Values are the mean \pm SEM of triplicate experiments. a) $p<0.05$; b) $p<0.01$. 
J. Y. Kim et al.: Chemical composition, antioxidant, anti-elastase, and anti-inflammatory activities of Illicium anisatum essential oil, Acta Pharm. 59 (2009) 289-300.

tein levels and pre-treatment with IAE inhibited these upregulations. On the other hand, IAE did not affect the expression of $\beta$-actin, a housekeeping gene. As shown in Fig. 2a, IAE reduced the expression of iNOS protein in a dose-dependent manner. Since the amounts of iNOS protein correlated with NO accumulation, these results suggest that IAE inhibited NO production by reducing the iNOS protein expression. We also found that the amount of the $72-\mathrm{kDa}$ COX-2 protein was increased by LPS and this increase was dose-dependently antagonized by the IAE (at 20, 50, and $100 \mu \mathrm{g} \mathrm{mL}-1$ ).

To further determine whether the inhibition of LPS-stimulated NO and PGE 2 production by IAE was mediated by the regulation of iNOS and COX-2 expression, RT-PCR analyses were performed. As shown in Fig. 2b, the expressions of iNOS and COX-2 mRNA were significantly elevated in macrophages treated with LPS $\left(1 \mu \mathrm{g} \mathrm{mL}^{-1}\right)$ compared to unstimulated cells (control). RT-PCR analyses revealed that IAE reduced iNOS and COX-2 mRNA without affecting the mRNA of $\beta$-actin, a housekeeping protein. The IAE also reduced the expression of iNOS and COX-2 protein in a dose-dependent manner. In general, these results indicate that the inhibitory effects of IAE on LPS-induced $\mathrm{NO}$ and $\mathrm{PGE}_{2}$ production are caused by iNOS and COX-2 suppression. Furthermore, the RT-PCR analyses indicate that mRNA levels of iNOS and COX-2 correlate with their protein levels. Therefore, the inhibitory effect of IAE on iNOS and COX-2 gene expression appears to be one of the mechanisms of the anti-inflammatory action of IAE. In conclusion, IAE actively suppresses the expression of genes implicated in inflammation.

\section{Cytotoxicity assay of IAE}

We examined the cytotoxic effects of IAE on human dermal fibroblasts and keratinocyte HaCaT cells. The essential oil exhibited low cytotoxicity in both fibroblast and
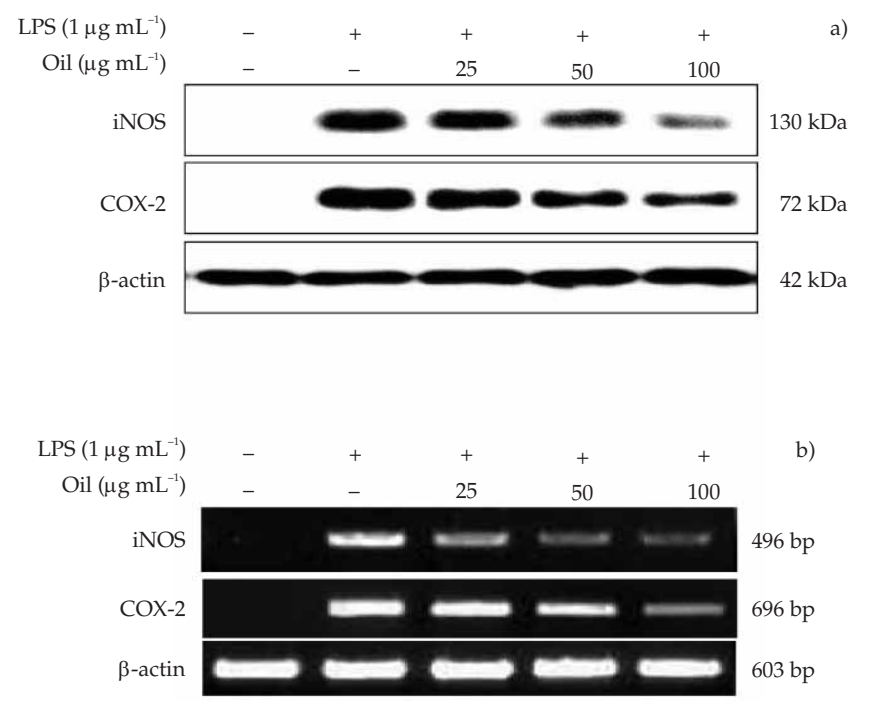

Fig. 2. Inhibitory effect of IAE on: a) protein and b) mRNA expression of iNOS and COX-2 in RAW 264.7 cells. 
J. Y. Kim et al.: Chemical composition, antioxidant, anti-elastase, and anti-inflammatory activities of Illicium anisatum essential oil, Acta Pharm. 59 (2009) 289-300.

HaCaT cells at concentrations below $100 \mu \mathrm{g} \mathrm{mL} \mathrm{mL}^{-1}$ (Fig. 3). Based on these results, we have concluded that IAE may be introduced as a possible therapeutic agent for skin health.
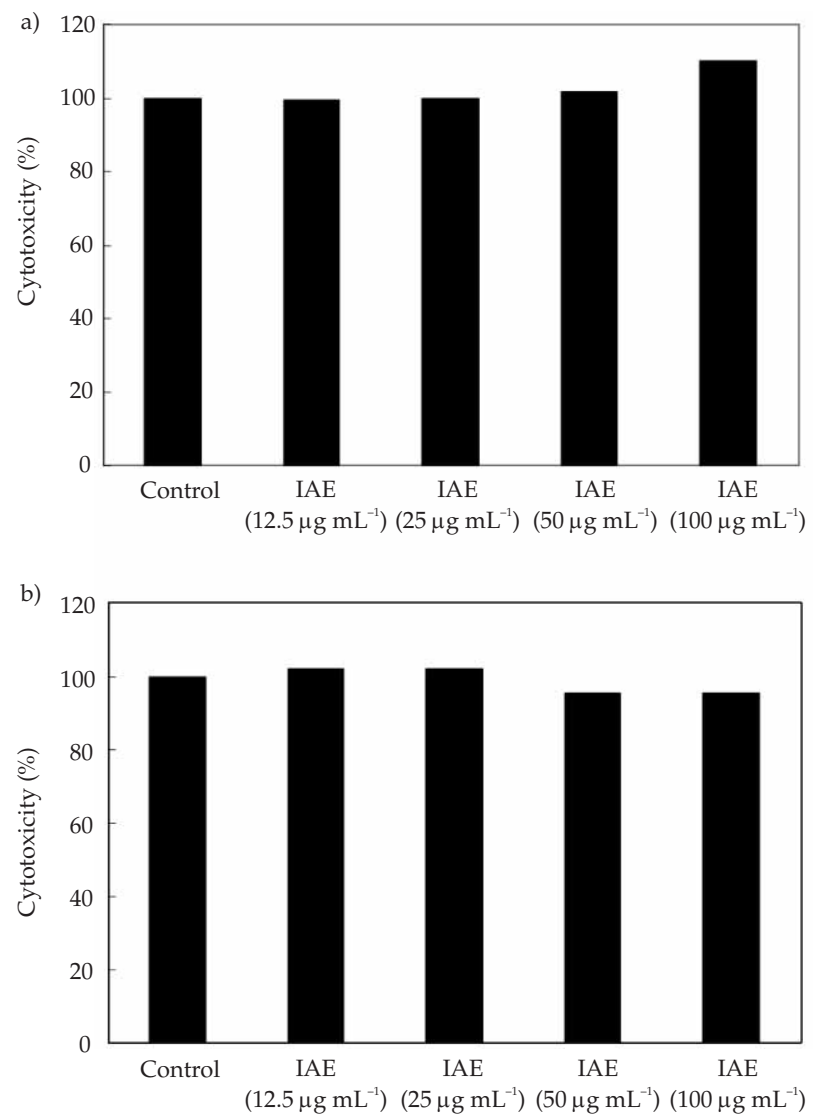

Fig. 3. Cell viabilities of: a) human normal fibroblast and b) HaCaT cells treated with IAE.

\section{CONCLUSION}

In conclusion, we demonstrated that IAE has good antioxidant, anti-elastase and anti-inflammatory effects and low cytotoxicity in human cell lines. Therefore, according to these results, we suggest that IAE may be employed as an effective therapeutic agent to promote skin health. To the best of our knowledge, this is the first report providing a scientific basis for the cosmetic use of IAE.

Acknowledgments. - This research was supported by the Regional Technology Innovation Program (RTI04-02-07), which is managed by the Ministry of Knowledge and Economy, Korea. 
J. Y. Kim et al.: Chemical composition, antioxidant, anti-elastase, and anti-inflammatory activities of Illicium anisatum essential oil, Acta Pharm. 59 (2009) 289-300.

\section{REFERENCES}

1. P. Minodier, P. Pommier, E. Moulène, K. Retornaz, N. Prost and L. Deharo, Star anise poisoning in infants, Arch. Pediatr. 10 (2003) 619-621; DOI: 10.1016/S0929-693X(03)00274-4.

2. H. Y. Kim and J. H. Oh, Screening of Korean forest plants for rat lens aldose reductase inhibition, Biosci. Biotechnol. Biochem. 63 (1999) 184-188; DOI: 10.1271/bbb.63.184.

3. H. Y. Kim and K. Kim, Protein glycation inhibitory and antioxidative activities of some plant extracts in vitro, J. Agric. Food Chem. 51 (2003) 1586-1591; DOI: 10.1021/jf020850t.

4. H. Y. Kim and M. H. Kang, Screening of Korean medicinal plants for lipase inhibitory activity, Phytother. Res. 19 (2005) 359-361; DOI: 10.1002/ptr.1592.

5. M. Shibuya, K. Abe, Y. Nakahashi and S. Kubota, Phenolic components from leaf oil of Illicium anisatum L., Chem. Pharm. Bull. 26 (1978) 2671-2673; DOI: 10.1248/cpb.26.2671.

6. Y. Kudo, J. I. Oka and K. Yamada, Anisatin, a potent GABA antagonist, isolated from Illicium anisatum, Neurosci. Lett. 25 (1981) 83-88; DOI: 10.1016/0304-3940(81)90105-1.

7. J. Y. Kor and D. W. Choi, Quantitative determination of glutamate mediated cortical neuronal injury in cell culture by lactate dehydrogenase efflux assay, J. Neurosci. Meth. 20 (1987) 83-89; DOI: 10.1016/0165-0270(87)90041-0.

8. M. Fernández, J. C. Ríos, A. Jos and G. Repetto, Comparative cytotoxicity of alachlor on RTG-2 trout and SH-SY5Y human cells, Arch. Environ. Contam. Toxicol. 51 (2006) 515-520; DOI: $10.1007 /$ s00244-005-0086-8.

9. M. M. Bradford, A rapid and sensitive method for the quantitation of microgram quantities of protein utilizing the principle of protein-dye binding, Anal. Biochem. 72 (1976) 248-254; DOI: 10.1016/0003-2697(76)90527-3.

10. W. B. Cook and A. S. Howard, The essential oil of Illicium anisatum Linn., Can. J. Chem. 44 (1966) 2461-2464; DOI: 10.1139/v66-371.

11. N. Mimica-Dukić, B. Bozin, M. Soković, B. Mihajlović and M. Matavulj, Antimicrobial and antioxidant activities of three Mentha species essential oils, Planta Med. 69 (2003) 413-419; DOI: 10.1055/ s-2003-39704.

12. S. Kordali, A. Cakir, A. Mavi, H. Kilic and A. Yildirim, Screening of chemical composition and antifungal and antioxidant activities of the essential oils from three Turkish artemisia species, J. Agric. Food Chem. 53 (2005) 1408-1416; DOI: 10.1021/jf048429n.

13. R. Thirugnanasampandan, R. Jayakumar, V. Narmatha Bai, E. Martin and K. J. Rajendra Prasad, Antiacetylcholinesterase and antioxidant ent-Kaurene diterpenoid, melissoidesin from Isodon wightii (Bentham) H. Hara, Nat. Prod. Res. 22 (2008) 681-688; DOI: 10.1080/14786410801990625.

\section{$S A \check{Z} E T A K$}

\section{Kemijski sastav, antioksidativno djelovanje, inhibicija elastaze i protuupalno djelovanje eteričnog ulja biljke Illicium anisatum}

JI-YOUNG KIM, SANG-SUK KIM, TAE-HEON OH, JONG SEOK BAIK, GWANPIL SONG, NAM HO LEE i CHANG-GU HYUN

Eterično ulje biljke Illicium anisatum dobiveno destilacijom vodenom parom analizirano je plinskom kromatografijom-spektrometrijom masa (GC-MS). Identificirane su pedeset i dvije komponente eteričnog ulja, a glavna komponenta je eukaliptol (21,8\%). Ispitivanje antioksidativnog djelovanja te djelovanja na elastazu ukazuju na umjerenu spo- 
J. Y. Kim et al.: Chemical composition, antioxidant, anti-elastase, and anti-inflammatory activities of Illicium anisatum essential oil, Acta Pharm. 59 (2009) 289-300.

sobnost hvatanja DPPH radikala i inhibicije elastaze. Kako bi se objasnio mehanizam protuupalnog djelovanja eteričnog ulja I. anisatum (IAE), ispitan je učinak na moduliranje produkcije dušikovog(II) oksida (NO) i prostaglandina $\mathrm{E}_{2}\left(\mathrm{PGE}_{2}\right)$ iz aktiviranih makrofaga. Rezultati ukazuju da je IAE učinkovit inhibitor LPS-inducirane produkcije NO i $\mathrm{PGE}_{2}$ u RAW 264.7 stanicama. Inhibitorno djelovanje popraćeno je smanjenjem ekspresije iNOS i COX-2 proteina i iNOS i COX-2 mRNA. Kako bi se odredilo može li se IAE sigurno primijeniti na ljudsku kožu, citotoksični učinci IAE određeni su kolorimetrijskim MTT testom $u$ humanim dermalnim fibroblastima i keratinocitima HaCaT. IAE je pokazao nisku citotoksičnost pri koncentraciji $100 \mu \mathrm{g} \mathrm{mL}-1$. Temeljem ovih rezultata IAE se može smatrati potencijalnim sredstvom protiv starenja i protuupalnim sredstvom u kozmetičkim pripravcima. Međutim, dodatni in vitro i in vivo testovi nužni su za potvrdu njegove sigurnosti i učinkovitosti.

Ključne riječi: Illicium anisatum, Illicium religiosum, Illicium japonicum, kemijski sastav, kozmetika, $D P P H$, elastaza, upala

Research Group for Cosmetic Materials, Jeju Biodiversity Research Institute (JBRI), Jeju Hi-Tech Industry Development Institute (HiDI), Jeju 699-943, Korea

Department of Chemistry, Cheju National University, Jeju 690-756, Korea 